\title{
Perceived ethical leadership in relation to employees' organisational commitment in an organisation in the Democratic Republic of Congo
}

\section{Author:}

Jeremy Mitonga-Monga'

Frans Cilliers ${ }^{1}$

\section{Affiliation:}

${ }^{1}$ University of South Africa

\section{Correspondence to:}

Dr. Jeremy Mitonga-Monga, Department of Industrial and Organisational

Psychology,

University of South Africa (Unisa),

P.O. Box 392,

Pretoria 0003 ,

South Africa

Tel. no.:

+27124292344

E-mail:

mitonmj@unisa.ac.za

DOI:

$10.15249 / 10-1-122$

\section{Keywords:}

ethical leadership; organisational commitment; Democratic Republic of the Congo

\section{Abstract}

The aim of this study is to determine the relationship between ethical leadership and organisational commitment. A crosssectional quantitative survey approach was used, with a nonprobability purposive sample of 839 employees from a railway organisation in the Democratic Republic of the Congo. The results indicate that ethical leadership perceptions have a significant influence on the level of organisational commitment. The study further indicates that ethical leadership predicted employees' affective, continuance, normative and overall commitment. These results add new insights to the construct of business ethics by showing that a positive perception of ethical leadership by employees is an important consideration in enhancing their organisational commitment.

\section{Introduction}

Researchers continue to focus on the importance of employees' commitment to the organisation. Indeed, meta-analytic research demonstrates that committed individuals are less likely to leave the organisation (Mathieu \& Zajac, 1990; Meyer \& Maltin, 2010); are more likely to be present at work (Meyer, Stanley, Herscovitch \& Topolnysky, 2002); perform effectively (Ismail \& Daud, 2014); and are regarded as valued assets for the organisation (Coetzee, Schreuder \& Tladinyane, 2013). According to Richardson, Cook and Hofmeyr (2011), to achieve success with regard to employees' commitment, organisations need ethical leaders - individuals with strong human and interactive skills and competencies such as fairness and respect - to inspire, motivate and encourage their employees' intention to stay. Employee commitment refers to an affective attachment to and involvement with a particular organisation (Mowday, Porter \& Steers, 1992; Nguyen, Felfe \& Fooken, 2014). Ethical 
leaders are seen as being responsible for inspiring moral values and ethical standards among their followers, and serve as role models who promote ethical behaviour and good morals by fostering employee-organisation relationships, which, in turn, lead followers to be emotionally attached to their organisation (Nelson \& Daniels, 2014).

Previous research has established that ethical leadership predicts employee outcomes such as job satisfaction, organisational commitment and organisational citizenship behaviour (Yates, 2014). However, the manifestation of this relationship has not yet been investigated in the organisational context of the Democratic Republic of the Congo (DRC). Research on the relationship between ethical leadership and organisational commitment is needed in the context of the developing world in order to clarify the universality of the influence of ethical leadership on the commitment levels of individuals.

\section{The DRC work context}

The DRC is situated in central Africa, with a population of more than 75 million and an abundance of natural resources, estimated at USD35 trillion. Despite these resources, the DRC remains one of Africa's poorest countries - the result of thirty-five years of dictatorial regime, political conflict, hyperinflation, mismanagement, corruption and unethical behaviour (Gilpin \& Boor, 2012). At present, the business sector is desperately trying to speed up institutional, economic, political and social reforms in order to ensure good governance, stability, and reduced corruption and unemployment (Beya, 2012). For example, in transportation, the political and economic challenges are addressed by a group of positive leaders who act with moral intent, trying to influence the level of employee commitment. The focus is on the railway sector, which has deteriorated significantly since independence (influencing railroads, waterways and roads). Recent efforts by the World Bank and African Development Bank (ADB) to address human resource issues of employee commitment have made little progress because of the lack of visionary, positive and ethical leadership (ADB, 2013). It is believed that the absence of effective leadership prevents employees from being committed to their organisations. It is unclear in this context how ethical leadership may influence employees' commitment levels. Specifically, the relationship between ethical leadership and employee commitment in the context of the workplace requires further investigation. Hence, the aim of this study was to examine the relationship between ethical leadership and employees' commitment to the organisation. The literature predicts that ethical leaders who act in a normative way, with appropriate behaviours such as fairness and honesty, and who exemplify principled behaviour, exhibit trustworthiness and take responsibility for their actions, will influence their employees' levels of organisational commitment (Philipp \& Lopez, 2013).

\section{Literature review}

The Ethical Leaders Work Behaviour (ELWB) model developed by Kalshoven, Den Hartog and De Hoogh (2011) and the Organisational Commitment (OC) model developed by Meyer and Allen (1997) provide a comprehensive overview of the theoretical and empirical lineage of this investigation. 
Ethical leadership is an important topic for scholars and practitioners and has been described in many ways. Kanungo and Mendonca (2001) and Hassan,Wright and Yukl (2014) note that ethical leaders engage in behaviours that benefit others, while Khuntia and Suar (2004) posit that ethical leaders incorporate moral principles into their values, beliefs and actions. Brown, Trevino and Harrison (2005:120) define ethical leadership as the "demonstration of normatively appropriate conduct through personal actions and interpersonal relationships, and the promotion of such conduct to followers through two-way communication, reinforcement, and decision making".

Organisational and management literature on leadership ethics suggests that ethics and integrity are at the centre of leadership studies (Ciulla, 1995; Laurie, 2014). The ethics of leadership facilitates an understanding of a leader's behaviour and provides an answer to the question of what differentiates effective from ineffective leadership. Northouse (2010) posits that ethics is central to leadership: it may impact on leaders' values and relationships with followers and help them to establish clear and congruent organisational values. Leaders' values are found to influence employees' intentions, ethical behaviour and attitudes (Watson, 2010). Ethical leadership has been found to influence employee behaviour in terms of organisational commitment and job satisfaction (Brown et al., 2005; Hassan, Wright \& Yukl, 2014).

Key aspects of ethical leadership include the following (Kalshoven, Den Hartog \& De Hoogh, 2011):

- Fairness - the extent to which the leader treats others with respect, honesty and fairness, and without favouritism.

- Power sharing - the extent to which the leader listens to followers' ideas and concerns and allows them a say in decision making.

- Role clarification - the extent to which the leader clarifies responsibilities, expectations and performance goals to ensure that followers know what is expected of them.

- People orientation - the extent to which the leader shows genuine care, respect and support for followers and ensures that their needs are met.

- Ethical guidance - the extent to which the leader communicates extensively with employees about ethics in terms of expectations, rules and rewards.

- Concern for sustainability - the extent to which the leader is concerned about impacts on stakeholders and society.

- Integrity - the extent to which the leader aligns what is said to what is done, keeps promises, behaves consistently, and is trusted and believed by followers.

\section{Employee commitment}

Organisational development practitioners and the literature on organisational behaviour have always valued the antecedents and consequences of employee commitment in explaining organisational behaviour (Zehir, Müceldili \& Zehir, 2012). In a turbulent and 
competitive economy (such as the one being experienced in the 21st century), employees' physical and emotional attachments to the organisation deteriorate, manifesting in increased absenteeism and turnover intention. Grant, Dutton and Rosso (2008) indicate that employees are more mobile and thus less dependent on a single organisation, which necessitates new ways of addressing their organisational attachment patterns and commitment (ibid.). Mowday et al. (1982) define organisational commitment as the relative strength of employees' identification with and involvement in a particular organisation, the extent to which they are likely to work on its behalf, and the possibility that they will stay in the organisation for the long term. Organisational commitment is based on the following three facets:

- Affective commitment - the extent to which employees are psychologically and emotionally attached to, identify with, and are involved in the organisation.

- Continuance commitment - the extent to which employees desire and consciously decide to stay with the organisation, which stems from the physical, cognitive and emotional investment they have made in the organisation and makes separation from it an unattractive option.

- Normative commitment - the extent of employees' sense of obligation to an organisation. It appears that employees feel that they ought to stay with an employer because it is morally right to continue to work for the same employer or organisation. Employees who feel that they are treated fairly and are thus motivated by their supervisors may develop a strong trust in and loyalty to their leader, followed by a sense of obligation to stay with the organisation (Zehir, Erdogan \& Basar, 2011). Similarly, Hansen, Alge, Brown, Jackson and Dunford (2013) add that when employees believe they are being treated unfairly, they are less likely to feel motivated to invest in the organisation or to develop sentiments of long-term commitment to the leadership or the organisation.

Consistent with the social exchange perspective, employees' emotional attachment to an organisation implies that they are more committed after having weighed the pros and cons, following their resignation or the intent to resign (Coetzee, Mitonga-Monga \& Swart, 2014; Kuo, 2013). Organisational commitment acts as a key factor in the connection between employee and organisation, provides cohesion, and stimulates employees to devote their efforts to addressing external influences and meeting customer demands (Kuo, 2013; Zehir, Sehitoglu \& Edgan, 2012). Organisational commitment can be differentiated from exchange-based forms of motivation and target-relevant attitudes. According to Madsen, Miller and John (2005), organisational commitment influences employees' behaviour and attitudes, even in the absence of extrinsic motivation. Employees who experience feelings of accomplishment and self-fulfilment tend to be psychologically and emotionally committed to the organisation (Hansen et al., 2013). Although the literature provides evidence about how ethical leadership relates to employees' commitment, the extent to which these associations are sustained in the DRC organisational context is unknown. 


\section{Goal of the study}

Based on the literature, the following research hypothesis was formulated:

$\mathrm{H}_{1}$ : Ethical leadership will positively relate to employees' organisational commitment.

The research question was formulated as follows: Do individuals' perceptions of ethical leadership relate to their level of commitment? The research is significant in terms of possible future human resource interventions with regard to promoting employee commitment. It is believed that such interventions will be successful in an environment where leaders act and treat others in an ethical manner (Žemguliené, 2013).

\section{Method}

\section{Research approach}

A quantitative research approach was followed to achieve the research objective. The study took the form of a cross-sectional research approach that generated data from a non-probability convenience sample.

\section{Sampling and procedure}

The research was conducted in a railway organisation in the DRC. All permanent employees were requested to complete the questionnaires. A non-probability purposive sample of $(\mathrm{N}=839)$ was used. The sample consisted of $68 \%$ men and $42 \%$ women. The participants were predominantly $(61 \%)$ in the age group 25 to 40 years (early and established career). The majority of participants (67\%) had between six and ten years of service in the organisation and most were well educated, with nearly $38 \%$ having an honours degree. Table 1 presents the demographic characteristics.

Table 1: Profile of respondents $(\mathrm{N}=839)$

\begin{tabular}{c|l|c|c}
\hline \multirow{4}{*}{ Gender } & Demographical variables & Frequency & Percentage \\
\hline \multirow{5}{*}{ Age } & Male & 571 & 68.1 \\
\cline { 2 - 4 } & Female & 268 & 31.9 \\
\hline \multirow{5}{*}{ Job tenure } & 25 years and younger & 212 & 25.2 \\
\cline { 2 - 4 } & 26-40 years & 529 & 63.1 \\
\cline { 2 - 4 } & $41-55$ years & 83 & 9.9 \\
\cline { 2 - 4 } & 56 and older & 15 & 1.8 \\
\hline \multirow{5}{*}{ Educational level } & Less than 5 years & 282 & 33.6 \\
\cline { 2 - 4 } & 6-10 years & 510 & 60.8 \\
\cline { 2 - 4 } & $11-20$ years and more & 47 & 5.6 \\
\cline { 2 - 4 } & National diploma & 185 & 22.1 \\
\cline { 2 - 4 } & Bachelor's degree & 235 & 28.0 \\
\cline { 2 - 4 } & Honours degree & 319 & 38.0 \\
\cline { 2 - 4 } & Masters degree and doctorate & 100 & 11.9 \\
\hline
\end{tabular}


The questionnaires were translated from English into French and back into English by a linguistic expert (to ensure validity).

The Ethical Leadership Work Questionnaire (ELWQ) (Kalshoven et al., 2011) was used to measure participants' perceptions of their leaders' ethical behaviour. The ELWQ is a self-report instrument containing 38 items using a five-point Likert scale ( $1=$ 'Strongly disagree', $5=$ 'Strongly agree'). Example items from the measure include "Is interested in how I feel and how I am doing"; "Holds me responsible for things that are not my fault"; "Permits me to play a key role in setting my own performance goal"; "Shows concern for sustainability"; "Clarifies integrity guidance"; "Clarifies priorities"; and "Keeps his/her promises". The ELWQ has evidenced good psychometric validity and reliability in the Netherlands and South Africa (Kalshoven et al., 2011). In this study, acceptable Cronbach alpha coefficients were obtained for all the measured dimensions, namely total ethical leadership (0.95); people orientation (0.85); fairness (0.83); power sharing (0.84); concern for sustainability (0.70); ethical guidance ( 0.82$)$; role clarification ( 0.86$)$; and integrity $(0.83)$ (see Table 2).

The Organisational Commitment Scale (OCS) (Meyer \& Allen, 1991) was used to measure participants' organisational commitment. The OCS is a self-report instrument containing 24 items using a five-point Likert scale ( $1=$ 'Strongly disagree', $5=$ ='Strongly agree'). Example items from the measure include "I would be happy to spend the rest of my career with the organisation"; "It would be very hard for me to leave my organisation right now"; and "I feel I have very few options to consider leaving this organisation". The OCS has evidenced internal consistency reliability ranging from 0.73 (normative) and 0.79 (continuance) to 0.85 (affective) (Meyer \& Allen, 1997). In this study, acceptable Cronbach alpha coefficients were obtained for all the measured dimensions, namely total organisational commitment (0.83); affective commitment (0.86); continuance commitment (0.88); and normative commitment (0.88) (see Table 2).

Using Nunnally and Bernstein's (2010) desirability guidelines for internal consistency or reliability coefficients of between 0.70 and 0.90 , both instruments gave reliable results.

\section{Statistical analysis}

Statistical analysis was performed using IBM SPSS Statistics for Windows, V22.0 (IBM Corp, 2013). Rasch analysis was used to evaluate uni-dimensionality, internal consistency and construct validity (Bond \& Fox, 2013).

Firstly, means, standard deviations, Cronbach alpha coefficients and correlations between the ELWQ and OCS variables were calculated. A cut-off point of 0.50 (large effect) was set for practical significance of all correlation coefficients (Cohen, 1992). Secondly, standard multiple regression analysis were used to determine whether the participants' perceptions of their leaders' ethical behaviour (measured by the ELWQ) predicted organisational commitment (measured by the OCS) (Tabachnick \& Fidell, 2013). In order to counter the probability of type I errors, it was decided to set the significance value at 
a 95\% confidence interval level $(p \leq 0.05)$. The $F$-test was used to test whether there was a significant relationship between the independent and dependent variables.

Prior to conducting the various regression analyses, collinearity diagnostics were examined to ensure that zero-order correlations were below the level of concern $(r \geq 80)$; that the variance inflation factors did not exceed 10; and that the tolerance values were close to 1.0 (Hair, Black, Babin \& Anderson, 2010).

\section{Results}

\section{Descriptive statistics and correlations}

Table 2 presents the descriptive statistics (mean, standard deviations and internal consistency Cronbach alpha) and correlations of the study variables, i.e. ethical leadership and employee commitment.

In terms of the ELWQ (ethical leadership) variables, concern for sustainability obtained the highest mean score $(M=4.04 ; S D=0.56)$; followed by ethical guidance $(M=4.02$; $\mathrm{SD}=0.65)$; power sharing $(M=4.00 ; \mathrm{SD}=0.63)$; people orientation $(M=3.99 ; \mathrm{SD}=.63)$; total ethical leadership $(M=3.98 ; S D=0.55)$; role clarification $(M=3.95 ; S D=0.70)$; integrity $(M=3.93 ; S D=.86)$; and fairness $(M=3.92 ; S D=0.55)$.

In terms of the OCS (organisational commitment) variables, the total sample scored the highest on the normative commitment $(M=4.13$; $S D=0.57)$ variable; followed by continuance commitment $(M=4.08 ; S D=.65)$; affective commitment $(M=4.07 ; S D=.55)$; and total organisational commitment $(M=4.07$; $S D=0.54)$. All three components imply a relatively high level of organisational commitment within the sample.

Table 2 also presents the significant correlation coefficients identified between the ELWQ and OCS variables. The inter-correlations ranged from $r \geq 0.46$ (medium practical effect size) to $r \geq 0.70$ (large practical effect size). These results showed that the zero-order correlations were below the threshold level of concern $(r \geq 0.80)$ of multi-collinearity. Total, affective, continuance and normative commitment were positively and significantly related to the ELWQ variables of people orientation, fairness, power sharing, concern for sustainability, ethical guidance, role clarification, integrity and total ethical leadership (with $\mathrm{p}$-values ranging between $\mathrm{p} \leq .01$ and $\mathrm{p} \leq .05$ ).

\section{Standard multiple regression}

Table 3 contains the regression results. The ethical leadership variables ethical guidance, role clarification, people orientation, power sharing and fairness showed a significant regression model $\left(F_{(7,834)}=103.98\right)$, accounting for $46 \%\left(R^{2}=0.46 ; P \leq 0.001\right.$; large practical effect) of the variance in affective commitment. More specifically, ethical guidance $(\beta=0.23 ; p \leq .01)$; role clarification $(\beta=0.23 ; p \leq .01)$; people orientation $(\beta=0.16 ; p \leq .01)$; power sharing $(\beta=0.10 ; p \leq .05)$; and fairness $(\beta=0.9 ; p \leq .01)$ contributed significantly towards explaining the proportion of variance in the OCS affective and continuance commitment variables. 


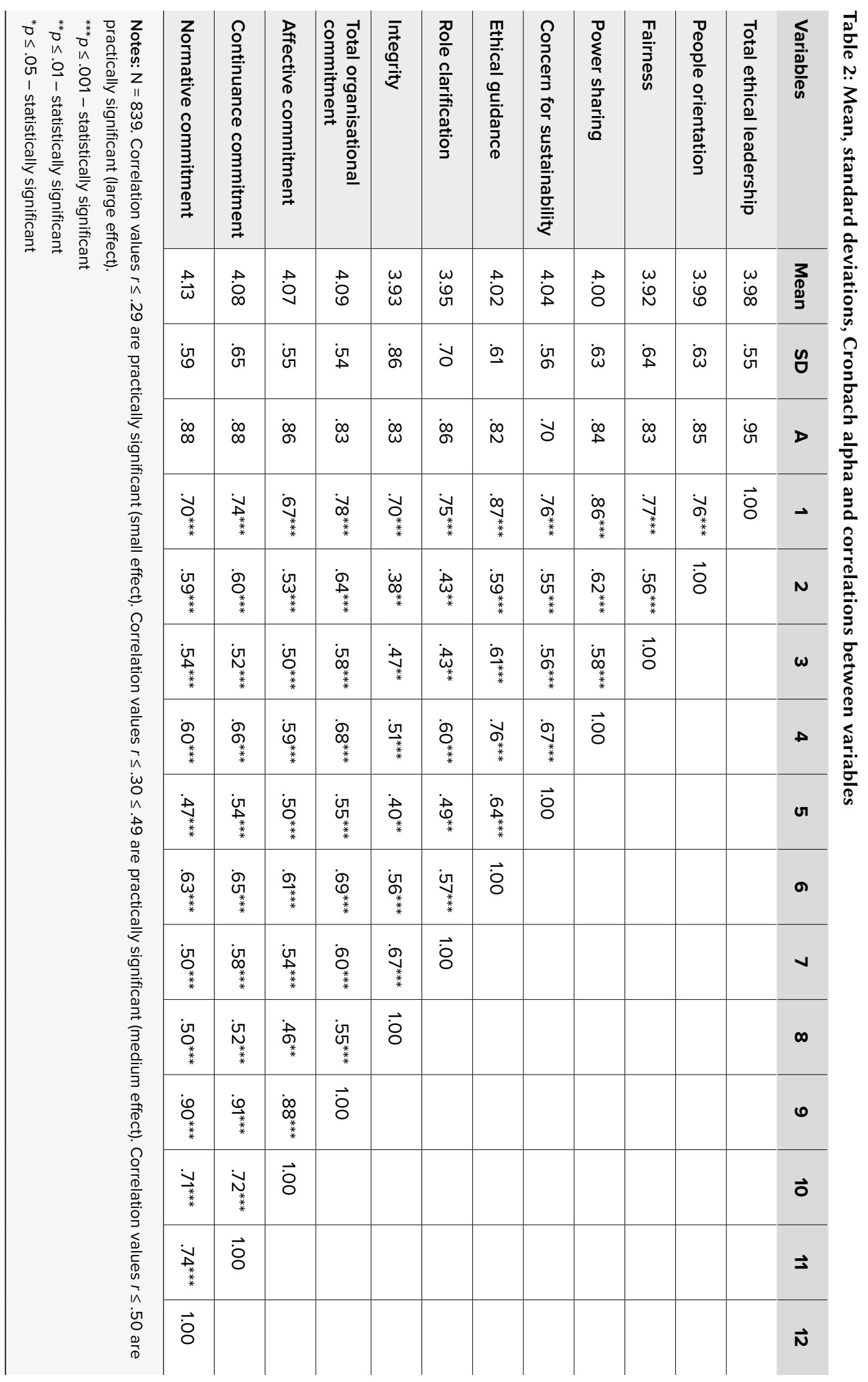


The ethical leadership variables of people orientation, ethical guidance, integrity, role clarification and power sharing produced a statistically significant regression model $\left(F_{(7,834)}=151.02\right)$, accounting for $56 \%\left(R^{2}=0.56 ; p \leq .01\right.$; large practical effect $)$ of variance in continuance commitment. More specifically, people orientation $(\beta=0.22 ; p \leq .01)$; ethical guidance $(\beta=0.20 ; p \leq .01)$; integrity $(\beta=0.19 ; p \leq .05)$; role clarification $(\beta=0.17 ; p \leq .01)$; and power sharing $(\beta=0.04 ; p \leq .01)$ contributed significantly towards explaining the proportion of variance in the OCS continuance commitment variable.

The ethical leadership variables of people orientation, ethical guidance, power sharing, fairness, integrity and role clarification produced a statistically significant regression model $\left(F_{(7,834)}=120.69\right)$, accounting for $50 \%\left(R^{2}=0.50 ; p \leq .01\right.$; large practical effect $)$ of the variance in normative commitment. More specifically, people orientation $(\beta=0.26$; $p \leq .01)$; ethical guidance $(\beta=0.23 ; p \leq .01)$; power sharing $(\beta=0.13 ; p \leq .01)$; fairness $(\beta=0.12 ; p \leq .01) ;$ integrity $(\beta=0.12 ; p \leq .01) ;$ and role clarification $(\beta=0.08 ; p \leq .05)$ contributed significantly towards explaining the proportion of variance in the normative commitment OCS variable.

The ethical leadership variables of people orientation, ethical guidance, role clarification, power sharing, fairness and integrity produced a statistically significant regression model $\left(F_{(7,834)}=194.71\right)$, accounting for $61 \%\left(R^{2}=0.61 ; \mathrm{p} \leq .01\right.$; large practical effect $)$ of variance in overall commitment. More specifically, people orientation $(\beta=0.24$; $\mathrm{p} \leq 0.000 .01)$; ethical guidance $(\beta=0.23 ; \mathrm{p} \leq .01)$; role clarification $(\beta=0.19 ; \mathrm{p} \leq .01)$; power sharing $(\beta=0.16 ; p \leq .01)$; fairness $(\beta=0.09 ; p \leq .05)$; and integrity $(\beta=0.08 ; t=2.48 ; p \leq .05)$ contributed significantly towards explaining the proportion of variance in the overall commitment variable.

\section{Discussion}

The aim of this study was to determine the relationship between ethical leadership and organisational commitment. The broader purpose was to determine whether ethical leadership significantly influenced employees' level of commitment in the railway industry in the DRC.

Overall, the results showed that ethical leadership did indeed influence employees' level of commitment towards the organisation. More specifically, ethical guidance, role clarification, people orientation, power sharing and fairness significantly and positively influenced affective commitment. People orientation, ethical guidance, integrity, role clarification and power sharing also positively influenced the participants' continuance commitment. The results also indicated that people orientation, ethical guidance, power sharing, fairness, integrity and role clarification positively influenced the participants' level of normative commitment, while people orientation, ethical guidance, role clarification, power sharing, fairness and integrity positively influenced their overall commitment to the organisation. 


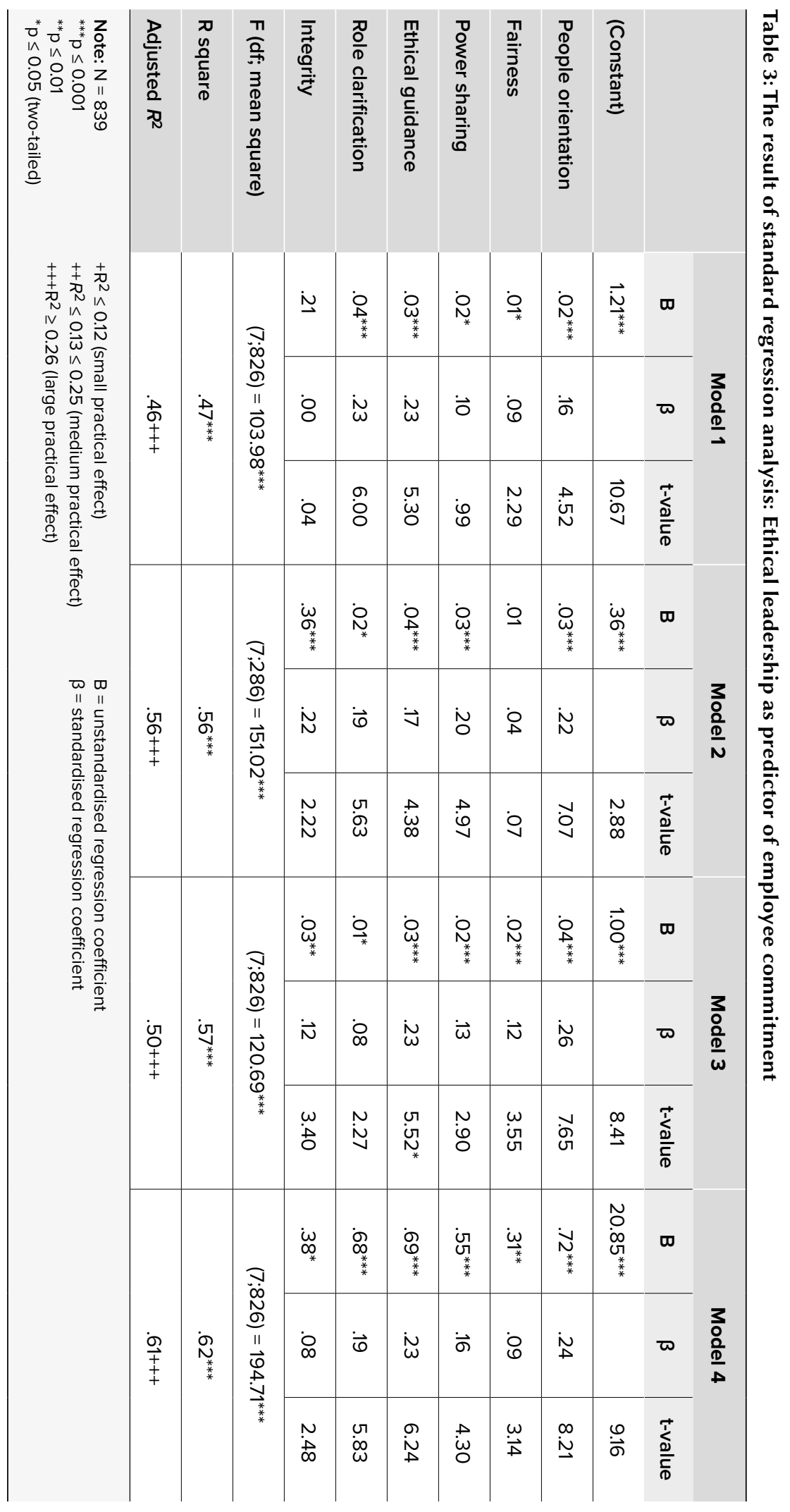


The analysis showed that ethical leadership is related to affective, normative, continuance and overall organisational commitment. A high level of people orientation and power sharing was related to high commitment. Therefore, when individuals are supported and allowed to have a say in the decision-making process, they are more likely to be committed to the organisation. This is supported by the findings of Kalshoven et al. (2011). Since a high level of integrity and fairness relates to high commitment, ethical leaders who are perceived to be consistent in their words and who treat employees fairly and with dignity are likely to positively influence employees' level of commitment (Nelson \& Daniels, 2014). Furthermore, a high level of ethical guidance, role clarification and concern for sustainability correlated with a high level of commitment. This indicates that when employees perceive their leaders to provide guidelines, clarify responsibilities and make them aware of ethical issues, they are likely to accept the goals and values of the organisation and to exert effort and have a strong desire to maintain membership in the organisation. These findings mirror those of Brundage and Koziel (2010); Ismail and Daud (2014); and Kalshoven et al. (2011). It is clear that ethical leadership has a strong relationship with employees' organisational commitment.

Affective commitment reflects an employee's emotional attachment to, identification with, and involvement in the organisation. This mindset also reflects a desire that develops when employees see their individual employment relationship as being in harmony with the goals and values of the organisation for which they are currently working (Meyer \& Herscovitch, 2001; Ponnu \& Tennakoon, 2009).

The regression analyses showed the following results:

- Affective commitment was predicted by ethical leadership (ethical guidance, power sharing and fairness). Hence, if employees perceive their leaders to be ethical - i.e. communicating expectations with regard to adhering to ethical rules, clarifying performance goals, involving followers in decision making and treating them fairly they will be psychologically and emotionally attached to the organisation (Ismail \& Daud, 2014).

- Continuance commitment was predicted by people orientation, ethical guidance, role clarification, integrity and power sharing. This implies that when leaders act ethically - i.e. they are concerned with the group's interests, promote ethical conduct, clarify responsibilities and performance goals, and are consistent in their words and deeds employees will be committed and inclined to stay in the organisation. These findings confirm previous research (Ezirim, Nwibere \& Emecheta, 2012).

- Normative commitment was predicted by people orientation, ethical guidance, power sharing, integrity and fairness, and role clarification. Employees who perceive their leaders to be ethical - i.e. promoting and rewarding ethical conduct, involving them in decision making, keeping promises, treating them with fairness, respect and honesty, and clarifying performance goals - employees will feel compelled to stay in the organisation. These findings confirm previous studies (Ko \& Hur, 2014; Miao, Newman, Schwarz \& Xu, 2013; Ram \& Prabhakar, 2011). 
The study showed a strong positive relationship between ethical leadership and organisational commitment. It adds value to the organisational commitment literature by shedding new light on how employees' perceptions of their leaders' ethical behaviour in the DRC's railway work environment relate to their levels of organisational commitment. The findings seem to support those of Ismail and Daud (2014), namely that employees who work under the supervision of ethical leaders who are honest and treat them with fairness and dignity are more likely to be psychologically and emotionally attached to the organisation and less likely to leave it. In practice, the knowledge gleaned from the observed association between the behaviour of perceived ethical leaders (in terms of people orientation, fairness, power sharing, concern for sustainability, ethical guidance, role clarification and integrity) and the participants' affective, continuance, normative and overall commitment may be useful in the retention of skilled employees in the DRC transport and railway sector.

Furthermore, the results have interesting implications for business leaders. In pursuit of organisational ethics, leaders at all levels should serve as role models by demonstrating ethical leadership before requiring employees to commit to the organisation and engage in ethical work behaviour. Given that ethical leadership has a positive impact on employees' attitudes and behaviour, organisations should hire people with strong ethical convictions and provide ethics training and ethical leadership programmes that can help them to not only develop ethical leadership skills, but also to influence their employees' level of commitment.

Although the study supports the importance of studying ethical leadership, it is not without limitations. Firstly, the sample consisted of employees employed in one organisation. The results cannot therefore be generalised to other organisations. Secondly, the researchers could not prove the causality of relationships, because the findings of the study used correlational data. Longitudinal studies should be conducted to establish the causal relationships between the variables.

Despite these limitations, the present study makes a meaningful contribution to the literature of business ethics, leadership and employee commitment. It expands the current understanding of the organisational dynamics of workplace ethics by theoretically and empirically demonstrating the value of ethical leadership with regard to employee outcomes such as commitment and satisfaction, and by specifying the ways in which ethical leaders affect these. With ethics being considered a universal value (Podger \& Menzel, 2014; Schwartz, 2005) and ethical leadership being endorsed across cultures, this study serves as an example for DRC researchers to examine the effects of ethical leadership on employee outcomes such as job satisfaction, organisational citizenship behaviour and employee engagement. It is recommended that future research be replicated with broader samples across various organisations and manufacturing organisations. This would help researchers to gain further insight into the effects of ethical leadership on employees' attitudes and behaviour. Moreover, in this study it would have been beneficial to measure all study variables from the perspectives of both leaders and subordinates. 
ADB (African Development Bank). 2013. Annual report 2013. ADB-ADF/BG/AR/2013. Tunis: African Development Bank Group.

Beya, M.R.M. 2012. Socio-Economic Collapse in the Congo: Causes and Solutions. Georgist Journal, 23 August. http://www.georgistjournal.org/2012/08/23/socio-economic-collapse-in-the-congo-causes-and-solutions/ [Accessed: 6 February 2016].

Bond, T.G. \& Fox, G.M. 2013. Applying the Rasch Model: Fundamental Measurement in the Human Sciences. (3rd Edition). New York, NY: Psychology Press.

Brett, G., Lambert, E.G., Hogan, N.L., Kim, B. \& Kelly, T. 2014. A further examination of the relationship between affective and continuance organisational commitment with correctional staff occupation burnout: A partial replication and expansion study. Criminal Justice and Behaviour, 41(10):1161-1177. DOI: $10.1177 / 0093854814539683$

Brown, M.E. \& Mitchell, M.S. 2010. Ethical ands unethical leadership: Exploring new avenues for future research. Business Ethics Quarterly, 20(4):583-616. DOI: 10.5840/beq201020439

Brown, M.E. \& Trevino, L.K. 2006. Ethical leadership: A review and future directions. The Leadership Quarterly, 17:595-616. DOI: 10.1016/j.leaqua.2006.10.004

Brown, M.E., Trevino, L.K. \& Harison, D.A. 2005. Ethical leadership: A social learning perspective for construct development and testing. Organisational Behaviour and Human Decision Processes, 97(2):117-134. DOI: 10.1016/j.obhdp.2005.03.002

Brundage, H. \& Koziel, M. 2010. Retaining Top Talent Still a Requirement for Firms. Journal of Accountancy, May 2010:38-44.

Chin, Y., Sung, S.Y., Choi, J.N. \& Kim, M.S. 2015. Top management ethical leadership and firm performance: Mediating role of ethical and procedural justice climate. Journal of Business Ethics, 129(1):1-17.

Ciulla, J.B. 1995. Leadership ethics: Mapping the territory. Business Ethics Quarterly, 5(1):5-28. DOI: $10.2307 / 3857269$

Ciulla, J.B. 2004. Ethics, the heart of leadership. (2nd Edition). Westport, CT: Praeger.

Coetzee, M., Mitonga-Monga, J. \& Swart, B. 2014. Human resource practices as predictors of engineering staff's organisational commitment: Original research. South African Journal of Human Resource Management, 12(1):1-9. DOI: 10.4102/sajhrm.v12i1.604

Coetzee, M., Schreuder, D. \& Tladinyane, R. 2013. Employees' work engagement and job commitment: The moderating role of career anchors. South African Journal of Human Resource Management, 12(1):572-584.

Cohen, J. 1992. Quantitative methods in psychology: A power primer. Psychological Bulletin, 112(1):153-159. DOI: 10.1037/0033-2909.112.1.155

Den Hartog, D.N. \& De Hoogh, A.H.B. 2009. Ethical leadership: The positive and responsible use of power. In: Tjsovold, D. \& Van Knippenberg, B. (eds). Power and Interdependence in Organisations. Cambridge, UK: Cambridge University Press.

Detert, J.R. \& Trevino, L.K. 2010. Speaking up to higher-ups: How supervisor and skip-level leaders influence employee voice. Organisational Sciences, 21:249-270. DOI: 10.1287/orsc.1080.0405

Dixon, M.L. \& Hart, L.K. 2010. The impact of path-goal leadership styles on work group effectiveness and turnover intention. Journal of Managerial Issues, 22(1):52-69.

Ezirim, C.B., Nwibere, B.M. \& Emecheta, B.C. 2012. The influence of corporate culture on organisational commitment: The Nigerian experience. International Journal of Business and Public Administration, 9:155-180.

Garland, B., Horgan, N.L., Kelley, T., Kim, B. \& Lambert, E.G. 2013. To be or not to be committed: The effects of continuance and affective commitment and absenteeism and turnover intent among private prison personnel. Journal of Applied Security Research, 8:1-28. DOI: 10.1080/19361610.2013.738402

Gilpin, R. \& Boor, B. 2012. Instability in the DRC. Washington, DC: United States Institute of Peace. http:// www.usip.org/publications/instability-in-the-drc [Accessed: 18 June 2015]. 
Grant, A.M., Dutton, J.E. \& Rosso, B.D. 2008. Giving commitment: Employee support programs and pro-social sense making process. Academy of Management Journal, 51(50):898-918. DOI: 10.5465/AMJ.2008.34789652

Hair, J., Black, W., Babin, B. \& Anderson, R. 2010. Multivariate data analysis. Upper-Saddle River, NJ: Prentice Hall.

Hansen, D., Alge, B.J., Brown, M.E., Jackson, L.C. \& Dunford, B.B. 2013. Ethical leadership: Assessing the value of a multifoci social exchange perspective. Journal of Business Ethics, 115:435-449. DOI: 10.1007/ s10551-012-1408-1

Hassan, S., Wright, B.E. \& Yukl, G. 2014. Does ethical leadership matter in Government? Effects on organisational commitment, absenteism and willingness to report ethical problem. Public Administration Review, 74:333-343. DOI: 10.1111/puar.12216

Hoffman, B.J., Bynum, B., Piccolo, R. \& Sutton, A.W. 2011. Person-organisational value congruence: How transformational leadership influences group effectiveness. Academy of Management Journal, 54:771-796. DOI: 10.5465/AMJ.2011.64870139

IBM Corp. 2013. IBM SPSS Statistics for Windows. Version 22.0. Armonk, NY: IBM Corp.

Imran, H., Arif, I., Cheema, S. \& Azeem, M. 2014. Relationship between job satisfaction, job performance, attitudes towards work, and organisational commitment. Entrepreneurship and Innovation Management Journal, 2(2):135-144.

Ismail, I.B. \& Daud, Y.B. 2014. Influence of ethical leadership towards organisational commitment. International Journal of Scientific and Research Publications, 4(9):1-6.

Kalshoven, K. \& Den Hartog, D.N. 2011. Ethical leaders' behaviour and leader effectiveness: The role of prototypicality and trust. International Journal of Leadership Studies, 5:102-119.

Kalshoven, K., Den Hartog, D.N. \& De Hoogh, A.H.B. 2011. Ethical leadership at work questionnaire (ELWQ): Development and validation of a multidimensional measure. Leadership Quarterly, 22:51-69. DOI: 10.1016/j.leaqua.2010.12.007

Kanungo, R.N. \& Mendonca, M. 2001. Ethical leadership and governance in organisations: A preamble. Canadian Journal of Administrative Sciences, 18:241-243. DOI: 10.1111/j.1936-4490.2001.tb00259.x

Khuntia, R. \& Suar, D. 2004. A scale to assess ethical leadership of Indian private and public sector managers. Journal of Business Ethics, 49(1):13-26. DOI: 10.1023/B:BUSI.0000013853.80287.da

Kim, H.J., Tavitiyaman, P. \& Kim, W.G. 2009. The effect of management commitment to service on employee service behaviours: The mediating role of job satisfaction. Journal of Hospitality and Tourism Research, 33(3):369-390. DOI: 10.1177/1096348009338530

Kim, W.G. \& Brymer, R.A. 2011. The effects of ethical leadership on manager job satisfaction, commitment, behavioural outcomes, and firm performance. International Journal of Hospitality Management, 30:1020-1026. DOI: 10.1016/j.ijhm.2011.03.008

Ko, J. \& Hur, S. 2014. The impacts of employee benefits, procedural justice, and managerial trustworthiness on work attitudes: Integrated understanding based on social exchange theory. Public Administration Review, 74(2):176-187. DOI: 10.1111/puar.12160

Kuo, Y.K. 2013. Organisational commitment in an intense competition environment. Industrial Management and Data System, 113(1):39-59. DOI: 10.1108/02635571311289656

Laurie, A.Y. 2014. Exploring the relationship of ethical leadership with job satisfaction, organisational commitment and organisational citizenship behaviour. The Journal of Values-Based Leadership, 7(1):1-15.

Madsen, S.R., Miller, D. \& John, C.R. 2005. Readiness for organisational change: Do organisational commitment and social relationships in the workplace make a difference? Human Resource Development and Quarterly, 16(2):213-233. DOI: 10.1002/hrdq.1134

Maertz, C.P., Griffeth, R.W., Campbell, N.S. \& Allen, D.G. 2007. The effects of perceived organizational support and perceived supervisor support on employee turnover. Journal of Organizational Behavior, 28:1059-1075. DOI: 10.1002/job.472

Mathieu, J.E. \& Zajac, D.M. 1990. A review and meta-analysis of the antecedents, correlates, and consequences of organizational commitment. Psychological Bulletin, 108(2):171-194. DOI: 10.1037/0033-2909.108.2.171 
Mayer, D.M., Aquino, K., Greenbaum, R.L. \& Kuenzi, M. 2012. Who displays ethical leadership, and why does it matter? An examination of antecedents and consequences of ethical leadership. Academy of Management Journal, 55(1):151-171. DOI: 10.5465/amj.2008.0276

Meyer, J. \& Herscovitch, L. 2001. Commitment in the workplace toward a general model. Human Resource and Management Review, 11:299-326. DOI: 10.1016/S1053-4822(00)00053-X

Meyer, J.P. \& Allen, N.J. 1991. A three-component conceptualisation of organisational commitment. Human Resources Management Review, 1(1):61-98. DOI: 10.1016/1053-4822(91)90011-Z

Meyer, J.P. \& Allen, N.J. 1997. Commitment in the workplace: Theory, research and application. Thousand Oaks, CA: Sage.

Meyer, J.P. \& Maltin, E.R. 2010. Employee commitment and well-being: A critical review, theoretical framework and research agenda. Journal of Vocational Behavior, 77(2):323-337. DOI: 10.1016/j.jvb.2010.04.007

Meyer, J.P., Stanley, D.J., Herscovitch, L. \& Topolnytsky, L. 2002. Affective, continuance and normative commitment to the organisation: A meta-analysis of antecedents, correlates and consequences. Journal of Vocational Behavior, 61(1):20-52. DOI: 10.1006/jvbe.2001.1842

Miao, Q., Newman, A., Schwarz, G. \& Xu, L. 2013. Participative leadership and the organizational commitment of civil servants in China: The mediating effects of trust in supervisor. British Journal of Management, 24(1):76-92. DOI: 10.1111/1467-8551.12025

Mogotsi, I.C., Boon, J.A.H. \& Fletcher, L. 2011. Knowledge-sharing behaviour and demographical variables amongst secondary school teachers in and around Gaborone, Botswana. South African Journal of Information Management, 13(1):420-426. DOI: 10.4102/sajim.v13i1.420

Mowday, R.T., Porter, L.Y. \& Steers, R. 1982. Employee-organisation linkage: The psychology of commitment, absenteeism, and turnover. San Diego, CA: Academic Press.

Nelson, J.A. \& Daniels, M.K. 2014. Leadership, perceptions, and turnover intentions: Why stay? Electronic Journal of Business Ethics and Organization Studies, 19(1):6-13.

Neubert, M.J., Carlson, D.S., Kacmar, M., Roberts, J.A. \& Chonko, L.B. 2009. The virtuous influence of ethical leadership behaviour: Evidence from the field. Journal of Business Ethics, 90:157-170. DOI: 10.1007/s10551009-0037-9

Nguyen, P., Felfe, J. \& Fooken, I. 2014. Interaction effects of dual organisational commitment on retention in international assignments: The case of Western expatriates in Vietnam. International Journal of Human Resource Management, 12:1-21.

Northouse, P.G. 2010. Leadership: Theory and Practices. (5th Edition). Thousand Oaks, CA: Sage.

Nunnally, C.J. \& Bernstein, I.H. 2010. Psychometric theory. New York, NY: McGraw-Hill.

Philipp, B.L.U. \& Lopez, P.D.J. 2013. The moderating role of ethical leadership: Investigating relationships among employee psychological contracts, commitment, and citizenship behaviour. Journal of Leadership and Organizational Studies, 20(10):1-12. DOI: 10.1177/1548051813483837

Piccolo, R.F., Greenbaum, R., Den Hartog, D.N. \& Folger, R. 2010. The relationship between ethical leadership and core job characteristics. Journal of Organizational Behaviour, 31(2):259-278. DOI: 10.1002/job.627

Podger, A. \& Menzel, D.C. 2014. East-West Values and Ethical Leadership in China: Symposium Introduction. Public Integrity, 16(2):159-164. DOI: 10.2753/PIN1099-9922160203

Ponnu, C.H. \& Tennakoon, G. 2009. The association between ethical leadership and employee outcomes: The Malaysian case. Journal of Business Ethics and Organization Studies, 14(1):21-32.

Quintana, T.A., Park, S. \& Cabrera, Y.A. 2014. Assessing the effects of leadership style on employees' outcomes in international luxury hotels. Journal of Business Ethics, 129(2):1-21.

Ram, P. \& Prabhakar, G.V. 2011. An enquiry into the mediatory role of employee engagement: Evidence from the hotel industry in Jordan. Far East Journal of Psychology and Business, 5(2):41-59.

Resick, C.J., Hanges, P.J., Dickson, M.W. \& Mitchelson, J.K. 2006. A cross-cultural examination of the endorsement of ethical leadership. Journal of Business Ethics, 63:345-359. DOI: 10.1007/s10551-005-3242-1 
Richardson, A., Cook, J. \& Hofmeyr, K. 2011. How leaders generate hope in their followers. South African Journal of Labour Relations, 35(2):47-66.

Ruiz-Palomino, P., Ruiz-Amaya, C. \& Knor, H. 2011. Employee organisational citizenship behaviour:The direct and indirect impact of ethical leadership. Canadian Journal of Administrative Sciences, 28(3):244-258. DOI: 10.1002/cjas.221

Saif, S.K., Nawaz, A., Jan, F.A. \& Khan, M.I. 2012. Synthesizing the theories of job satisfaction across the cultural, attitudinal dimensions. International Journal of Contingency Research and Business, 3(90):1382-1396.

Salami, O.S. 2008. Demographic and psychological factors predicting organisational commitment among industrial workers. Antropologica, 10(1):31-38.

Schwartz, M.S. 2005. Universal moral values for corporate codes of ethics. Journal of Business Ethics, 59(1,2):27-44.

Shariff, M.M. \& Scandura, T.A. 2013. Do perceptions of ethical conduct matter during organisational change? Ethical leadership and employee involvement. Journal of Business Ethics, 124(2):185-196. DOI: 10.1007/ s10551-013-1869-x

Tabachnick, B.G. \& Fidell, L.S. 2013. Using multivariate statistics. (6th Edition). Boston, MA: Pearson.

Van Dyk, J. \& Coetzee, M. 2012. Retention factors in relation to organisational commitment in medical and information technology services. Southern African Journal of Human Resources Management, 10(2):433-444. DOI: 10.4102/sajhrm.v10i2.433

Wang, L. \& Ashcraft, R.F. 2014. Organisational commitment and involvement: Explaining the decision to give to associations. Non-Profit and Voluntary Sector Quarterly, 43(25):615-835.

Watson, T. 2010. Leader ethics and organisational commitment. URL, 3(1):16-26.

Wiltermuth, S.S., Monin, B. \& Chow, R.M. 2010. The orthogonality of praise and condemnation in moral judgement. Social Psychological and Personality Science, 1(4):302-410. DOI: 10.1177/1948550610363162

Wiza, M. \& Hlanganipai, N. 2014. The impact of leadership styles on employee organisational commitment in higher learning institutions. Mediterranean Journal of Social Sciences, 5(4):135-143. DOI: 10.5901/ mjss.2014.v5n4p135

Wright, T.A. \& Bonett, D.G. 2002. The moderating effects of employee tenure on the relation between organisational commitment and job performance: A meta-analysis. The Journal of Business Ethics, 101:509-523.

Yates, L.A. 2014. Exploring the relationship of ethical leadership with job satisfaction, organisational commitment, and organisational citizenship behaviour. Journal of Values-Based Leadership, 7(1):1-15.

Zehir, C., Erdogan, E. \& Basar, D. 2011. The relationship among charismatic leadership, ethical climate, job satisfaction and organisational commitment in companies. Journal of Global Strategic Management, 10:49-59. DOI: 10.20460/JGSM.2011515797

Zehir, C., Müceldili, B. \& Zehir, S. 2012. The moderating effect of ethical climate on the relationship between job satisfaction and organisational commitment: Evidence from large companies in Turkey. ProcediaSocial and Behavioural Sciences, 58:734-743. DOI: 10.1016/j.sbspro.2012.09.1051

Zehir, C., Sehitoglu, Y. \& Erdogan, E. 2012. The Effect of Leadership and Supervisory Commitment to Organizational Performance. Procedia - Social and Behavioral Sciences, 58:207-216. DOI: 10.1016/j. sbspro.2012.09.994

Žemguliené, J. 2013. Perceived ethical leadership and job involvement in the economic-specific context. Organisations and Markets in Emerging Economies, 4(1):43-55. 